DOI: $10.15290 / \mathrm{bsl} .2016 .08 .10$

\author{
Szymon Trusewicz \\ Wydział Filologiczny \\ Uniwersytet w Białymstoku \\ e-mail: sztr@o2.pl
}

\title{
Egzystencjalno-fenomenologiczne czytanie poezji Eugeniusza Tkaczyszyna-Dyckiego
}

Grzegorz Jankowicz, pisząc o poezji Eugeniusza Tkaczyszyna-Dyckiego, zauważa, że jest to twórczość, której podstawowe tematy, takie jak śmierć, choroba psychiczna, płynna tożsamość seksualna, matka, "wchodzenie" w język i w pisanie, są w istocie podporządkowane jednemu głównemu tematowi - poezji i jej stosunkowi do rzeczywistości ${ }^{1}$. Jako przykład Jankowicz wskazuje wiersz XLIV. Modlitwa za zmartych ${ }^{2}$. Próbując znaleźć odpowiednią formułę dla opisania relacji poezji i rzeczywistości, Jankowicz tworzy pojęcie "wiersza permanentnego": "takiego wiersza, który trwa, podaje dalej, przekazuje, odwleka (przynajmniej próbuje odwlec) koniec" [O, s. 208]. Tkaczyszn-Dycki pisze o tym w pierwszych wersach Modlitwy za zmarlych: "do Chotynieckich i Kulczyckich / postaram się wrócić odkąd nie ulega / wątpliwości że Chotynieccy / pochodzili z Chotyńca koło Lubaczowa". Poeta, jak zauważa Jankowicz, zamiast po spójnik „skoro" w drugim wersie, sięga po zaimek "odkąd" wskazujący na relację czasową, jaka zachodzi pomiędzy poetą i czekającą na opowiedzenie historią Chotynieckich i Kulczyckich. Zadanie "powrotu do imion”, które stawia przed sobą autor, jest odwlekane dzięki użyciu czasownika „starać się" w aspekcie dokonanym [O, s. 212]. Aby lepiej zdefiniować użyte przez siebie pojęcie wiersza permanentnego, Jankowicz przywołuje, za pośrednictwem aforyzmu Friedricha Schlegla, pojęcie

1 G. Jankowicz, Obietnica, posłowie do: E. Tkaczyszyn-Dycki, Podaj dalej, Poznań 2012, s. 209. Kolejne cytaty lokalizuję w tekście głównym, oznaczając je skrótem O.

2 E. Tkaczyszyn-Dycki, Imię i znamie, Wrocław 2012, s. 48. 
poematu. Jak twierdzi badacz, zarówno Tkaczyszyna-Dyckiego, jak i Schlegla interesują relacje na linii poezja-rzeczywistość-język, obaj patrzą na "gmach języka” jako na „ruinę" całościowego sensu. Każdy wiersz to próba sklecenia pozostałych po budowli ułomków - „fragmentów, strzępów wersów, pojedynczych słów, niewyrychtowanych myśli”. Jankowicz pisze, że "tam, gdzie kiedyś stało zabetonowane sensem domostwo, teraz oglądamy wielość języków i słów" [O, s. 208]. Jednak wizja poezji i języka wyrażona przez Schlegla i ta, którą Jankowicz odczytuje z poezji Tkaczyszyna-Dyckiego, znacząco się różnią. W przypadku poematu wizja całości wciąż jest możliwa, nadzieję niesie uprzednia wobec niego mowa - „sieć nazw, imion własnych, która chroni człowieka przed osunięciem się w otchłań materii" [O, s. 208]. Z kolei koncepcja wiersza permanentnego wyraża niebezpieczeństwo zapadnięcia się porządku symbolicznego i w konsekwencji dotknięcia nagiej materii. Rozbity poemat, według Schlegla, mimo swojej fragmentaryzacji, niemożliwości powstania nowego całościowego sensu, trzymał w ryzach żywioł rzeczywistości. Pokruszone słowa, jak pisze Jankowicz, przynajmniej pozwalały przykryć - niczym konfetti - rzeczywistość. Dyskurs poetycki Tkaczyszyna-Dyckiego niesie ze sobą diagnozę nieco bardziej pesymistyczną, w której pęknięcia, rysy i przetarcia $\mathrm{w}$ materii słowa grożą zerwaniem się Rzeczy z łańcucha języka i „ontologiczną rebelią” [O, s. 215]. Największym problemem nie jest, jak u Schlegla, słabość języka, problem z nakładaniem na rzeczywistość nieprzystających do niej pojęć. Jest nim obecnie, i o tym mówi zdaniem Jankowicza Tkaczyszyn-Dycki, sama poezja, która nie spełnia wyłącznie szlachetnej misji opisu rzeczywistości. Nie istnieje już bowiem instancja uprzednia wobec poezji, nie ma gmachu języka, a ruiny dawnego poematu wcale nie służą zakrywaniu rzeczywistości, a tym bardziej nie dają nadziei na powstanie nowej budowli. Stanowią raczej „pamięć” poezji o swojej dawnej świetności, sprawiają, że rości sobie ona pretensje do całościowego opisu [O, s. 216-217], wedle zasad estetyki zupełnie anachronicznej. Być poetą, korzystać z usług poezji, oznacza od teraz zmagać się z podwójnym problemem: po pierwsze spełniania wymagań wobec świata, czyli doboru jak najbardziej adekwatnych słów, po drugie zaspokajania poezji, która „żąda” całości. Oba zadania wzajemnie się wykluczają, co sprawia, że poeta trwa w „metafizycznym impasie” [O, s. 217].

\section{Po obu stronach lustra}

„Poematowi”, „porządkowi symbolicznemu”, ,językowi”, „poezji”, „imionom”, ,mowie" przeciwstawia Jankowicz „materię”, „,́́wiat”, ,,rzeczywistość”, ,Rzecz", ,"chaos" i w końcu „Realne”. Badacza nie interesuje jednak 
za bardzo, co stanie się z jednostką, gdy ta, zmęczona "grą na zwłokę" osunie się w chaos Realnego lub odda się w niewolę estetyki poezji. Co prawda Jankowicz pisze, że „poeta próbuje ocalić imię własne (cudze i swoje)” [O, s. 217], ale na problem spogląda raczej okiem filozofa, myśląc o procesie twórczym $\mathrm{w}$ perspektywie realizowanej przez autora wybranej „ideologii estetycznej" [O, s. 209]. O Lacanowskim Realnym więcej pisze Grzegorz Tomicki w książce Po obu stronach lustra. O poezji Eugeniusza Tkaczyszyna-Dyckiego ${ }^{3}$. Według niego, podobnie jak według Jankowicza, groźba konfrontacji z „magmą Realnego" stanowi jeden z głównych tematów poezji Tkaczyszyna-Dyckiego. Kwestię tę rozważa jednak Tomicki w perspektywie psychoanalizy i psychologii, wychodząc niejednokrotnie poza układ wiersza, mierząc się z kategorią autora.

Składające się na książkę Tomickiego rozdziały można, jak pisze sam autor, czytać jako osobne całości. Perspektywa, którą przyjmuje badacz jest dosyć spójna i rzeczywiście można by ją w uproszczeniu nazwać „egzystencjalną lub psychologiczną" [P, s. 10]. Przy czym autor nie odwołuje się do egzystencjalizmu wprost, ale za pośrednictwem teorii Ronalda Davida Lainga. Trzeba dodać, że posługuje się on również pojęciami z zakresu psychoanalizy Jacquesa Lacana i filozofii Slavoja Žižka. Z treści pracy wynika jeszcze jeden podział i pokrywa się on z chronologią powstawania rozdziałów, którą odsłania autor we wstępie. Pierwszy rozdział pracy "Wszystko to sa rzeczy niepewne". O wcielonym i niewcielonym "ja" w poezji Eugeniusza Tkaczyszyna-Dyckiego różni się od późniejszych, dotyczących powtórzenia, słów-kluczy i ironii. Widać, że ten najdłuższy spośród wszystkich rozdziałów, nie był pisany razem z pozostałymi. Nie jest to zarzut, a jedynie uzasadnienie dla traktowania książki jako składającej się z dwóch części (rozdziału pierwszego i pozostałych). Różnią się one bowiem na tyle, że wymagają oddzielnego omówienia.

\section{Dwudzielne , ja"}

Rozdział "Wszystko to sa rzeczy niepewne". O wcielonym i niewcielonym "ja" w poezji Eugeniusza Tkaczyszyna-Dyckiego został przez Tomickiego napisany specjalnie do omawianej publikacji, w przeciwieństwie do pozostałych, które powstały jako część poświęconego tematyce mityzacji w poezji współczesnej doktoratu. Rzeczywiście wyróżnia się on objętością i spójnym zapleczem

\footnotetext{
${ }^{3}$ G. Tomicki, Po obu stronach lustra. O poezji Eugeniusza Tkaczyszyna-Dyckiego, Szczecin 2015.
} Kolejne cytaty lokalizuję w tekście głównym, oznaczając je skrótem P. 
teoretycznym, który stanowi praca Ronalda Davida Lainga Podzielone "ja"4. Wskazać tu trzeba na dwie istotne cechy tej pracy. Laing, a za nim Tomicki, stosuje egzystencjalno-fenomenologiczną (pojęcie Lainga) wykładnię schizofrenii, kwestionując tym samym jasny podział na to, co normalne i patologiczne. Stosuje on również $w$ swoich metodach hermeneutyczne rozumienie wypowiedzi pacjenta. $Z$ tego względu podejście Lainga mieści się w nurcie zwanym „antypsychiatrią". Badacze zaliczani do tej grupy poddają krytyce używane w psychiatrii pojęcia, które według nich służą przede wszystkim współkonstruowaniu dyskursu zdrowia i choroby psychicznej. Pełni on ważną funkcję społeczną, pozwalając wykluczyć jednostki przeżywające problemy niemieszczące się w ramach normalności. Antypsychiatrzy kwestionują nazywanie chorobą schorzeń nieposiadających u swoich podstaw wad organicznych czy zaburzeń fizjologicznych ${ }^{5}$. Dotyczy to przede wszystkim schizofrenii, która według Lainga jest raczej „specjalną strategią, którą osoba [...] obmyśla, by móc przetrwać w sytuacji nie do wytrzymania" ${ }^{\prime}$. Szczególnie interesujące w kontekście książki Tomickiego wydaje się spojrzenie Lainga na analizę wypowiedzi i zachowań pacjentów. Autor Podzielonego "ja" porównuje dwie perspektywy interpretacji tekstu: formalną i hermeneutyczną, odnosząc je odpowiednio do metod psychiatrii klinicznej i własnego stanowiska. Wzbogaca on tym samym proces analizy wypowiedzi i zachowań pacjentów o „wczucie się" lekarza, powołując się na teorię interpretacji Wilhelma Diltheya ${ }^{7}$. Laing bardziej niż pacjenta dotkniętego chorobą stara się widzieć jednostkę, której czyny stanowią „wyraz jej własnego sposobu bycia-w-świecie" ${ }^{\prime \prime}$. W opisie subiektywnego oglądu świata jednostki Laing sięga do pojęć fenomenologii i egzystencjalizmu. Mówi on przede wszystkim o "ontologicznej niepewności" podmiotu, nabytej przy okazji traumtycznych doświadczeń. W odpowiedzi na taką sytuację osoba dotknięta schizofrenią wypracowuje mechanizmy, które pozwolą jej chronić swoje ,ja”. Skutkuje to różnymi praktykami, które odpowiadają ogólnemu schematowi podzielenia ",ja" na zewnętrzne i wewnętrzne, prawdziwe-wsobne i to przeznaczone "dla świata". Teorię Lainga, negującą rozpatrywanie subiektywnych oglądów

4 R.D. Laing, Podzielone "ja", przeł. M. Karpiński, Poznań 1995. Tomicki korzysta z wydania z 2004 roku.

5 J. Wójcik, Inspiracje humanistyczne w psychiatrii: uwagi na marginesie "Filozofii medycyny" Henrika R. Wulffa, Stinga Andura Pedersena i Rabena Rosenberga, Warszawa 1993, s. 273, „Medycyna Nowożytna" 1997, t. 4, nr 1-2, s. 158.

6 R.D. Laing, Polityka doświadczenia. Rajski ptak, Warszawa 1996. Cyt. za: J. Wójcik, Inspiracje humanistyczne w psychiatrii, s. 159.

7 R.D. Laing, Podzielone "ja", s. 38.

8 Tamże, s. 39. 
rzeczywistości w kategoriach prawdy i fałszu, uznaje się $\mathrm{w}$ psychoterapii za użyteczną, uzupełniającą medyczny ogląd zjawiska schizofrenii ${ }^{9}$.

Wyłożoną przez Lainga w Podzielonym "ja" teorię Tomicki odnosi do pojęcia „ponowoczesnej refleksyjności” Žižka, który mówi o utracie „skuteczności symbolicznej" współczesnego człowieka. Schizoidalność, rozumiana poza dualizmem normalne - patologiczne, określa zdaniem Tomickiego każdą osobowość i jest efektem ponowoczesnej rzeczywistości. To epoka, w której „wielki Inny już nie istnieje”, a porządek symboliczny nie ma już swojego punktu odniesienia [P, s. 45] ${ }^{10}$. Poezja Tkaczyszyna-Dyckiego dobrze oddaje, w opinii Tomickiego, doświadczenie współczesnego człowieka, którego dotyczy „,sytuacja rozbicia jedności intersubiektywnego świata oraz postępująca $\mathrm{z}$ nią równolegle dezorganizacja mitycznej struktury świata jednostkowego" [P, s. 14]. Odpowiadając samemu sobie na pytanie postawione w podrozdziale Co to ma wspólnego z poezją?, Tomicki pokazuje, w jaki sposób traktuje analizowaną twórczość:

jeżeli [...] wiersze Eugeniusza Tkaczyszyna-Dyckiego traktują o schizofrenii to przecież nie godzi się, abym jako badacz tych wierszy rozprawiał wyłącznie o chwytach, tropach i metaforach; ani nawet o parabazach, supozycjach, antymetabolach, paronomazjach, antyfrazach czy doświadczeniu estetycznym jako residuum prawdy. Wolałbym raczej podjąć temat, jaki proponuje mi autor, i porozmawiać trochę, powiedzmy, o schizofrenii [P, s. 51].

Rozmowa, którą chce podjąć za poetą badacz, rozwija się w podrozdziale Interpretacje i wykorzystuje streszczoną teorię podzielonego "ja" Lainga. Nie wdając się w szczegółowe interpretacje poszczególnych wierszy, należy zasygnalizować, że przyjmowana przez Tomickiego strategia lekturowa nie zawsze jest jasno określona. Autor nie zaznacza we wstępie, kto jest podmiotem jego analizy: Tkaczyszyn-Dycki czy „Dycio", podmiot wierszy. Dlatego problem ten powraca, niejako przy okazji, gdy autor formułuje tego typu zdania:

Nadświadomość - czy też inaczej: wyostrzona samoświadomość - odgrywa jednak o wiele bardziej zasadniczą rolę w życiu mówiącego w wierszu Dycia-poety (a także, jak można się domyślać, w życiu empirycznego autora) [P, s. 61].

Wierszowy Dycio, alter ego empirycznego Dyckiego (jego wcielone , ,ja"?), stara się potwierdzać własne istnienie także w inny charakterystyczny dla osób schizoidalnych i schizofreników sposób [P, s. 78].

9 J. Wójcik, Inspiracje humanistyczne w psychiatrii, s. 164.

10 Do sposobu rozumienia tych kategorii przez Tomickiego i stosowania ich do interpretacji poezji Tkaczyszyna-Dyckiego powrócę w dalszej partii tekstu, omawiając drugą część Po obu stronach lustra. 
Metoda obrony wierszowego Dycia - i empirycznego Dyckiego? - przed tym stanem rzeczy (stanem umysłu) jest jednak specyficzna [P, s. 110].

Nie do końca wiadomo, w jaki sposób Tomicki posługuje się teorią dwudzielnego „ja". Wydaje się, że interpretuje samą osobę Tkaczyszyna-Dyckiego, traktując proces pisania jako autoterapię poety. Jednak za pomocą niedopowiedzeń i przemilczeń badacz unika jasnej odpowiedzi. Trzeba by zapytać, czy problemów nie nastręcza teoria Lainga. Rodzi się bowiem wątpliwość, czy narzędzie hermeneutyczne wykorzystywane przez psychiatrę do celów terapeutycznych służy Tomickiemu do zrozumienia literatury czy psychiki autora? Nie można jednak zapomnieć, że Podzielone "ja" stanowi wprawdzie główny, ale niejedyny kontekst, w jakim Tomicki interpretuje poezję Tkaczyszyna-Dyckiego.

\section{Realne}

W drugiej części pracy, w której autor podejmuje temat powtórzenia, słów-kluczy i ironii w poezji Tkaczyszyna-Dyckiego, często przywoływanym pojęciem jest Lacanowskie Realne. Pojawiło się ono również w przywoływanym eseju Jankowicza. O ile jednak Jankowiczowi Realne służy do rozważań o „estetycznej ideologii” poety, o tyle Tomicki Realne i całą psychoanalizę Jacquesa Lacana i filozofię Slavoja Žižka czyni podstawą dla rozważań skoncentrowanych wokół podmiotu. Wizję rzeczywistości w twórczości poety interpretuje Tomicki przy pomocy trzech pojęć opisujących różne obszary ludzkiej psychiki: Wyobrażeniowego, Symbolicznego i Realnego. Porządek Wyobrażeniowy dotyczy powstawania obrazu swojego ,ja”. Oglądanie siebie w lustrze pozornie służy dziecku do upewnienia się o spójności swojego "ja", w istocie jednak rodzi niezacieralną granicę pomiędzy nim i jego obrazem. Wyobrażeniowe to proces poszukiwania własnego ",ja", próba powrotu do fikcji o jedności podmiotu ${ }^{11}$. „Mały inny", pisany małą literą, to inny z porządku wyobrażeniowego, odróżniający się od „wielkiego Innego", który należy do porządku Symbolicznego. Symboliczne obejmuje sferę znaczeń, większość tego, co nazywamy „rzeczywistością”, od języka do prawa, przecinając również sferę społeczną ${ }^{12}$. Jak zauważa Tomicki, porządek Symbolicznego jawi się jako „pełen pęknięć, luk i niespójności,

11 T. Myers, Slavoj Žižek, przeł. J. Kutyła, w: Žižek. Przewodnik Krytyki Politycznej, Warszawa 2009, s. 41.

12 Tamże. 
ujawnianych szczególnie drastycznie »W epoce ponowoczesnej refleksyjności«" [P, s. 150], co bardzo dobrze widać w świecie wykreowanym przez Tkaczyszyna-Dyckiego. Trzecim porządkiem, obok Wyobrażeniowego i Symbolicznego, jest Realne. Oznacza ono to, czego nie sposób poznać językiem, to, co opiera się symbolizacji. Realne, obnażające luki Symbolicznego, bezpośrednio zagraża poczuciu tożsamości podmiotu, również podmiotu poezji Tkaczyszyna-Dyckiego, który czuje się „zdezorientowany, zdecentrowany, zdezintegrowany" [P, s. 153].

W rozdziale "Twoim domem jest zmarty”. Słowa-klucze w poezji Eugeniusza Tkaczyszyna-Dyckiego Tomicki analizuje wyrazy, które występują w tej twórczości częściej niż pozostałe. Tego typu metoda, służąca wejrzeniu w semantykę autora i badaniom nad stylistyką, $\mathrm{u}$ Tomickiego została wsparta Lacanowską psychoanalizą. Według badacza umieszczone intencjonalnie słowa-klucze służą Tkaczyszynowi-Dyckiemu do zbudowania specyficznej wizji świata w dziele literackim. Tomicki nazywa te wyrazy, za Lacanem, "punktami zapikowania". Najważniejsze spośród nich to: Dom, Matka, Choroba, Przyjaciel, Wiara, Ciało, Śmierć, Krzyk, Kości, Bóg (Pan). Słowa-symbole o „silnym ładunku tradycji” mają pomóc, według Tomickiego, w stworzeniu nowego porządku symbolicznego, przełamując niejako ponowoczesną nadrefleksyjność podmiotu. Badacz pisze o słowach-kluczach:

Wprowadzając je do swojej poezji autor "przemienia nieład w porządek", nie tylko poetycki, nie tylko dyskursywny, ale i - pośrednio - także egzystencjalny. Poeta pisze: Dom, Śmierć, Matka, Choroba i już pomiędzy tymi pojęciami-symbolami mogą być ustanawiane jakieś relacje, które z kolei pojęcia te określają, nadając im - jak i całemu światu przedstawionemu - „pozytywną treść”: znaczącą i sensowną strukturę [P, s. 158].

Tomicki zdaje się więc wskazywać, że dzięki „odbudowie łańcucha znaczących" [P, s. 153], z użyciem wyróżnionych przez tradycję punktów zapikowania (Dom, Matka, Śmierć), podmiot może na nowo „wynaleźć" sposób egzystencji w nieuporządkowanym świecie. Jest to jednak istnienie, którego podstawy (punkty zapikowania) trzeba ustanawiać arbitralnie i cały czas na nowo, co skłania Tomickiego do mówienia o „performatywnym ustanawianiu określonych »faktów «" [P, s. 156]. Służąca do tego poezja pomaga wytworzyć wizję świata partykularną i uniwersalną zarazem, co nie pozostaje bez konsekwencji. Istnieją sfery Realnego, takie jak śmierć, które wymykają się wszelkiej symbolizacji. Według Tomickiego poeta jest tego świadom, bo opisując śmierć posługuje się językiem wieloznacznym i zmetaforyzowanym, w którym znaczenia i sensy nie zastygają w binarnych opozycjach, ale podlegają ciągłym przemianom [P, s. 166]. Co więcej, zdaniem badacza, poezja 
może funkcjonować właśnie na kształt Realnego. Ze względu na swój potencjał przekształcania znaczeń poezja zawsze zachowuje, niczym Realne, jakąś niepochwytną część, „nieuchwytną dla języka dyskursywnego wieloznaczność i wielowymiarowość" [P, s. 168]. Staje się, jak Realne, „areną dialektyki, gdzie sprzeczności mogą łączyć się ze sobą" [P, s. 168]. Skoro poezja przyjmuje tak ważną funkcję, staje się domem dla samego poety, co Tomicki łączy z pojawiającym się u Tkaczyszyna-Dyckiego wersem „poezja jako miejsce na ziemi". Jankowicz przestrzegłby przed przesadnym zaufaniem wierszowi, który rości sobie pretensje do opisu całościowego, co bywa dyktowane pamięcią o dawnej, modernistycznej estetyce. Tomicki ten aspekt pomija, zauważając co prawda, że jest to „(niemożliwa) ucieczka przed niewysławialnym, traumatyzującym doświadczeniem śmierci w sen języka”, ważniejsze są jednak dla badacza terapeutyczne skutki dyskursu poetyckiego. Jego zdaniem próba wysłowienia $\mathrm{w}$ poezji doświadczenia śmierci pozwala, przynajmniej częściowo, oswoić traumę umierania [P, s. 168].

\section{Tkaczyszyn-Dycki i Dycio}

Próba interpretacji poezji Tkaczyszyna-Dyckiego w taki sposób, w jaki czyni to Grzegorz Tomicki jest interesująca dzięki swojemu odniesieniu do realiów epoki ponowoczesnej, o której tyle pisze Žižek. Niesie rzecz jasna niebezpieczeństwo uniwersalizacji przesłania twórczości autora Kochanki Norwida, przed czym broni się Tomicki, podkreślając egzystencjalny wymiar praktyki poetyckiej Tkaczyszyna-Dyckiego. Sposób, w jaki to robi, budzi jednak zastrzeżenia z kilku względów. Czytanie literatury w kontekście psychologii musi zacząć się od wyjaśnienia podstawowego problemu: czego, a może kogo, dotyczy analiza? Jest to pytanie tym bardziej palące, że Tomicki stosuje teorię dwudzielnego ,ja” na przykładzie literatury, która na pewnej schizoidalności opiera swoją budowę. Nie tylko w przypadku bohatera wierszy, ale napięcia, które rodzi się pomiędzy nim a autorem. Pominąć to pytanie, to poddać się poetyckiemu natchnieniu, dać się unieść duchowi poezji Tkaczyszyna-Dyckiego. Wystawia to, rzecz jasna, dobre świadectwo samemu poecie, jednak naraża badacza i jego pracę na krytykę, czyniąc odczytanie nieprzydatnym naukowo.

W przypadku Tomickiego największe zastrzeżenia budzi sposób, w jaki autor przeplata ze sobą dwa różne poziomy interpretacyjne. Mimo że posługuje się pojęciem podmiotu/ ,ja" lirycznego i autora, oba te światy miesza ze sobą, przykładając wnioski wyciągnięte z interpretacji „psychiki” bohatera wierszy na samego poetę. Nie zabezpiecza również wywodu wstępem, 
który uzasadniłby taką postawę. W niewiele mówiącym fragmencie pierwszego rozdziału, opisywanej powyżej części Co to ma wspólnego z poezją?, Tomicki zaznaczył jedynie, że wiedza z zakresu psychologii i psychiatrii okazuje się „przydatna” do badania literatury, również tej, w której problematyka psychologiczna nie jest poruszana explicite. Tomicki pisze, że wiedza psychologiczna przydatna jest „przy analizowaniu każdego ludzkiego zachowania, a więc także zachowań autorów, czytelników, bohaterów literackich czy podmiotów lirycznych" [P, s. 53] i jest to być może sedno problemów związanych z tą pracą. Tym fragmentem autor zdaje się zrównywać świat wewnątrz tekstu ze światem na zewnątrz tekstu, mimo że nie potwierdza tego używana terminologia (przez całą pracę mowa o podmiocie wierszy i autorze) i teoria (dla Lainga tekst był metaforą zapożyczoną z hermeneutyki na potrzeby analizy wypowiedzi pacjentów). O ile można udowodnić przykładanie teorii psychologicznych do postaci literackich, o tyle już porównywanie ich z prawdziwymi osobami wydaje się kontrowersyjne. Zupełnie błędne jest natomiast mieszanie obu porządków, do których te postaci należą. Czynić to trzeba mimo, a nie $\mathrm{z}$ powodu, jak pisze Tomicki, "tych wszystkich zbieżności, analogii czy podobieństw" między oboma światami. W przypadku omawianej pracy skutkuje to, z jednej strony, "łataniem” dziur w ontologii podmiotu wierszy cechami samego autora (przywoływaniem słów z wywiadu), z drugiej strony - przenoszeniu na poetę cech podmiotu, co stwarza wrażenie wejrzenia $w$ psychikę samego autora. Tak poprowadzoną psychoanalizę można uznać nie tylko za błędną, ale i wątpliwą ze względów etycznych. $Z$ jednej strony bowiem, $\mathrm{w}$ ramach logiki wywodu, niezbędne jest określenie podmiotu interpretacji, a w przypadku zmiennej perspektywy, uzasadnienie takiego postępowania. $\mathrm{Z}$ drugiej strony, na poziomie refleksji filozoficznej, można by zapytać, jaką postawę Tomicki przyjmuje wobec Innego, o którym przecież w swojej pracy pisze, a którego nie można dookreślić ${ }^{13}$. Autor, jak będzie można zobaczyć na przykładach z tekstu, czyni to nieprzekonywająco.

Pewne metodologiczne dopowiedzenia mogłyby zostać niewyrażone wprost, a wplecione przez autora w samą interpretację, co znosiłoby potrzebę jasnego określenia stanowiska we wstępie. Niestety rozsiane po treści Po obu stronach lustra uwagi nie realizują takiego założenia, co widać na przykła-

\footnotetext{
13 „Nieczytelność tekstu jest niemożliwością odpowiedzi na podstawowe pytanie: »Kim jest Inny?«. Możliwość pomylenia porządku transcendentalnego z językowym (retorycznym) wystawia zaś etykę czytania na ciągłe ryzyko śmieszności". P. Mościcki, W stronę innego narcyzmu. Literatura, miłość, etyka, „Przegląd Filozoficzno-Literacki” 2006, nr 2, s. 243. Por. J. Hillis Miller, The Ethics of Reading, New York 1987; M.P. Markowski, Zwrot etyczny w badaniach literackich, „Pamiętnik Literacki” 2000, nr 1, s. 239-244.
} 
dach. Jeszcze w pierwszej części, gdy Tomicki streszcza teorię, którą Robert David Laing przedstawił w Podzielonym "ja", czytamy, że:

owo pragnienie śmierci - choć prowadzące do psychozy, a w konsekwencji do bycia rzeczywiście martwym-za-życia - Laing postrzega jako w pewnym sensie „symulowane”, „udawane", tak jak w pewnym sensie „udawany" jest zresztą podział ,ja" na wcielone i niewcielone, wszystko to bowiem odbywa się w sferze wyobrażeń, fantazji [P, s. 103].

Słowa te, jak sugeruje Tomicki, odnoszą się do podmiotu wierszy Tkaczyszyna-Dyckiego, który „niewątpliwie odczuwa brak pierwotnego poczucia pewności ontologicznej" [P, s. 105]. Nie wzbudza również podejrzeń następująca uwaga: „wspominający zmarłych i piszący wiersze (podmiot liryczny wierszy Dyckiego, podobnie jak sam autor, jest poetą)", gdyż badacz cały czas wskazuje ,ja" liryczne jako podmiot interpretacji. Kilka stron dalej, podsumowując podrozdział, pisze jednak Tomicki: „Metoda obrony wierszowego Dycia - i empirycznego Dyckiego? - przed tym stanem rzeczy (stanem umysłu) jest jednak specyficzna" [P, s. 110], żeby w innym fragmencie skierować interpretację $\mathrm{w}$ stronę samego poety: „autor $\mathrm{z}$ perspektywy czasu poddaje przypadki swojego życia narracyjnej, mitologizującej, poetyckiej obróbce" [P, s. 114]. Podobne niejasności można odnaleźć w całej książce.

Pozostając przy jednym szczególnym fragmencie pracy, omówionym w poprzedniej części, dotyczącym Realnego [podrozdział Dom. Zamieszkiwanie Realnego?, P, s. 162-168], wskazać można kilka niesygnalizowanych przejść z jednego poziomu interpretacji na drugi. Punkt zapikowania - dom - pojawia się, jak pisze Tomicki, „w wielu tekstach Tkaczyszyna-Dyckiego” i "przypisuje się mu jednak różne znaczenia” [P, s. 162]. Założyć chyba trzeba, że to poeta przypisuje mu różne znaczenia, umieszczając dom w różnych kontekstach. Następnie, niejako poza intencją autora, „znaczenia nakładają się na siebie, wchodzą ze sobą w dialektyczne związki, dynamizujące poetycką wypowiedź" [P, s. 162]. Tomicki przywołuje fragmenty wierszy Tkaczyszyna-Dyckiego i, wskazując $w$ nich na traumę podmiotu, pisze: „Wiersz opisuje wprawdzie jednostkowe doświadczenie lirycznego »ja« - takie jest jego prymarne znaczenie - ale posiada też wymiar uniwersalny [...]" [P, s. 163]. Wywód jest jasny, Tomicki mówi o podmiocie lirycznym jako o konstrukcji psychicznej, która podlegać może traumie i zaburzeniom dysocjacyjnym, czyni przy okazji nieco ogólną uwagę o „uniwersalnym znaczeniu" domu. Nadrzędną instancją, konstruującą podmiot w poezji, jest w tym wypadku Tkaczyszyn-Dycki. $W$ omawianym fragmencie Tomicki pokazuje inne cechy , ja" lirycznego. Wypowiada się ono na temat 
poezji. Badacz pisze: „pisanie wierszy jest natomiast przedstawione jako poetyckie krążenie wokół das Ding". Nie dziwi to wcale, wielokrotnie zaznaczano, że wykreowany w tej poezji „Dycio” obdarowany został przez Tkaczyszyna-Dyckiego jego własnymi doświadczeniami, dzięki czemu tak ważnym tematem tej twórczości staje się napięcie między kreacją i autentyzmem ${ }^{14}$. Wywód traci na jasności dopiero $\mathrm{w}$ momencie przywołania postaci Slavoja Žižka. Jak dotąd bowiem Tkaczyszyn-Dycki dysponował sensami za pośrednictwem wpisanego $\mathrm{w}$ tę poezję podmiotu lirycznego i wszelkie działania Tomicki odnosił do tej wykreowanej postaci. Kiedy badacz pisze o „świecie poezji”, do którego jak „do snu” wyprowadza się „podmiot-poeta", to porusza się dalej na poziomie świata przedstawionego. W nim to swoją aktywność poetycką, traumy, doświadczenia opisuje podmiot. Do niego również badacz odnosi Realne Žižka-Lacana, biorąc tę teorię w pewien cudzysłów, stosując do analizy psychiki podmiotu w wykreowanym świecie przedstawionym. Tomicki wykorzystuje myśl Žižka, aby powiedzieć o Rzeczy niepoddającej się symbolizacji, czyli o śmierci. Musi jednak mówić o procesie symbolizacji w zastosowanym wcześniej cudzysłowie, to znaczy o napotykającym na problemy $\mathrm{z}$ opisem śmierci wewnątrztekstowym "Dyciu". Tymczasem pisze, że w celu poradzenia sobie $\mathrm{z}$ tym problemem "zarówno Žižek w swoich tekstach, jak i Dycki w wierszach stosują opisy niestandardowe" [P, s. 167]. Akapit, z którego pochodzi to zdanie, wprowadza zamieszanie do wywodu, bo dalsza interpretacja ponownie dotyczy podmiotu: „Przestrzeń zmarłego i przestrzeń podmiotu przynależą do różnych systemów, dwóch różnych światów" [P, s. 167]. Wedle całości wywodu, odnosić je trzeba by do świata przedstawionego. Mimo wprowadzającego chaos, nieco zagadkowego, poprzedniego akapitu, kolejna uwaga dotycząca Realnego i poezji dotyczy świata wykreowanego. Poezja pisana przez podmiot, przez tekstowego "Dycia”, "funkcjonuje właśnie w znacznej mierze na sposób owego paradoksalnego Realnego" [P, s. 167]. Zgodnie z logiką wywodu, zarówno poezja, jak i teoria Žižka wzięte są w cudzysłów. Kiedy Tomicki pisze w zakończeniu o poecie, który „wyprowadził się w sen / dla napisania bardzo osobnej książki”, musi mieć na myśli „Dycia", nie Tkaczyszyna-Dyckiego. Badacz nie kończy jednak w ten sposób całego rozdziału o słowach-kluczach. Ostatni podrozdział Śmierć. Ucieczka $w$ sen języka podejmuje myśl tam, gdzie zakończył się poprzedni fragment. Tomicki zaczyna od słów: „Poezja Tkaczyszyna-Dyckiego jawi się zatem, w pewnym jej wymiarze, jako (niemożliwa) ucieczka przed niewysławial-

14 Powracam do tego wątku w zakończeniu. Por. K. Hoffmann, Dubitatio. O poezji Eugeniusza Tkaczyszyna-Dyckiego, Szczecin 2012, s. 89-90. 
nym, traumatyzującym doświadczeniem śmierci w sen języka [...] [P, s. 168]". Autor dokonuje $\mathrm{w}$ tym momencie nieuprawnionego przejścia $\mathrm{z}$ poziomu wewnątrztekstowego, któremu poświęcił nie tylko poprzednią część, ale w zasadzie cały rozdział, na poziom zewnętrzny wobec tekstu. Szukając dla swojej pracy interpretacyjnej podsumowania, badacz ponownie zrównuje poetę Dycia z poetą Tkaczyszynem-Dyckim, poezję pisaną przez podmiot liryczny z poezją autora z krwi i kości. Jaśniejsze staje się (choć dalej niejasne ze względu na odmienność obu dyskursów) porównanie we wcześniejszej partii tekstu Žižka i Tkaczyszyna-Dyckiego. Rozmyło to niejako późniejsze, już i tak bardzo niejasne, sformułowanie "poeta”, którego użył Tomicki zamiast wcześniejszych Tkaczyszyn-Dycki/autor i podmiot/,ja" liryczne.

Szczegółowa interpretacja fragmentu pracy Tomickiego ukazuje jak w soczewce główny błąd, który popełnia autor - traktowanie podmiotu wierszy i ich autora jak gdyby byli ontologicznie tożsami. Początek i zakończenie rozdziału odnoszą się do Tkaczyszyna-Dyckiego: „poprzez słowa-klucze poeta wprowadza do swojej lirycznej narracji pewne zamieszanie" [P, s. 147], „zasadniczym tematem twórczości Tkaczyszyna-Dyckiego - który podejmuje on $\mathrm{w}$ swoim dziele $\mathrm{z}$ różnych perspektyw - jest zatem »Realne - niemożliwe jądro [...] «" [P, s. 179], natomiast część środkowa do podmiotu wewnątrztekstowego. Tomicki zmienia w sposób nieuzasadniony perspektywę interpretacyjną. Popełnia w ten sposób błąd, bo ostateczny wniosek o ucieczce Tkaczyszyna-Dyckiego w "sen języka" uzasadnia ucieczką w język wewnątrztekstowego „Dycia”. Problem, na który napotkał Tomicki, ma przynajmniej dwie przyczyny. Po pierwsze jest nią sama poezja Tkaczyszyna-Dyckiego, w której niewątpliwie obecne jest napięcie pomiędzy ,ja" lirycznym i samym poetą. Ono samo staje się interesującym, podejmowanym przez krytyków problemem. Zaniechanie jasnego ustosunkowania się do tego problemu rodzi trudności interpretacyjne, które autor sam na siebie sprowadza. Raz jeszcze trzeba podkreślić, że podział na świat wewnątrz tekstu i na zewnątrz, wprowadzany za sprawą kategorii podmiotu lirycznego i autora, wywołuje Tomicki. Po drugie, zastosowanie psychoanalizy Jacquesa Lacana i filozofii Slavoja Žižka na polu literatury wymaga pewnej ostrożności i konsekwencji. Użycie ich na poziomie świata przedstawionego dzieła literackiego może przynieść ciekawe rezultaty, choć nieco ograniczające wydźwięk zarówno poezji, jak i teorii. Byłaby to jednak interepretacja konsekwentna. Tomicki chce natomiast czytać Tkaczyszyna-Dyckiego wielowymiarowo, wykorzystując teorie bardzo zniuansowane pod względem pojęciowym. Stosowanie ich $\mathrm{w}$ interpretacji tej poezji wymaga finezji i dużej precyzji języka. 


\section{Pogranicze, margines, krawędź}

Czytanie literatury w świetle egzystencjalno-fenomenologicznej teorii Lainga, jak to czyni Grzegorz Tomicki, wydaje się pomysłem ciekawym, szczególnie $\mathrm{w}$ pierwszej części książki. Jest to jednak perspektywa zewnętrzna wobec samego tekstu, traktująca poezję jako jeden $\mathrm{z}$ wielu dyskursów i jako taka wymaga dowodów „z zewnątrz" poezji. Niestety w przypadku Tkaczyszyna-Dyckiego źródeł nie ma zbyt wiele, poza dwoma wywiadami i eseistyczną książką poety Zaplecze.

Mieszanie porządku kreacji i biografii to znamienna cecha twórczości Dyckiego, która z biegiem czasu stała się swego rodzaju strategią autora. Wzmocniona przez inne zachowania poety, m.in. odmawianie wywiadów, służy budowaniu jego legendy. Pisząc o tej twórczości, recenzenci nie zawsze dostrzegali specyfikę tych wierszy, chętnie popadając w skrajności. Wczesna recepcja poezji Tkaczyszyna-Dyckiego nie była wolna od odczytań ściśle biograficznych. Pisze o tym Andrzej Niewiadomski w artykule Poezja jako terapia (nie)możliwa:

Można bez zbytniego ryzyka pomyłki stwierdzić, iż „standardowe” odczytanie najistotniejszych wymiarów wierszy Dyckiego opiera się o penetrowanie umiejętnie podsycanej przez samego poetę i pełnej przekłamań krytycznych "legendy" biograficznej. Ośrodkiem zainteresowania staje się nie poezja, ale "oryginalność" egzystencji znacznie odbiegającej od współczesnej, redukującej tragizm, normy ${ }^{15}$.

Autor zauważa, że przedmiotem zainteresowania bywała nie sama poezja, ale egzystencjalny wymiar przeżyć $w$ niej zawartych. Była to lektura zorientowana na pacjenta, jednostkę będącą nośnikiem traum, chorób i przeżyć. Powstawał obraz przekłamany, bo nie uwzględniający świadomego używania przez Tkaczyszyna-Dyckiego konwencji autobiografizmu. Pisze o tym także Marcin Jaworski w artykule Rzeczywiste. Konkretne, gdzie zauważa, że poezji autora Imienia i znamienia nie da się czytać czysto biograficznie:

Czytelnik Dyckiego z łatwością znajdzie punkty wspólne między jego twórczością a poezją np. Rafała Wojaczka (rozchwiana tożsamość, erotyzm, relacje z matką, wyrafinowana forma etc.) i równie szybko dostrzeże, że Dycki odróżnia się przede wszystkim dystansem (nie zawsze ironicznym) wobec samej formy

\footnotetext{
15 A. Niewiadomski, Poezja jako terapia (nie)możliwa, http://portliteracki.pl/przystan/teksty/
} o-wierszach-eugeniusza-tkaczyszyna-dyckiego [dostęp 08.12.2016]. 
wiersza i do własnego statusu jako poety oraz umiejętnym balansowaniem między dosadnością a humorem. Warto zauważyć, że wbrew temu, co sugerował Niewiadomski, Dycki nie dorobił się, jak Stachura, Wojaczek czy Świetlicki, wyznawców legendy i raczej mu na tym nie zależało ${ }^{16}$.

Jaworski zgadza się z Niewiadomskim co do tekstowo-kreacyjnego rysu poezji Dyckiego, ale polemizuje $z$ tezą, że poeta stał się legendą i że odpowiedział w ten sposób na zapotrzebowanie czytelników spragnionych legend na miarę Wojaczka, Bursy i Stachury. Według badacza elementy biografii poety przeklętego służą autorowi Peregrynarza jedynie jako element budowanej biografii autora-bohatera własnych wierszy, która pisana jest „,na pograniczu, marginesie, kresie, krawędzi (literatury, państwa, społeczeństwa, kultury zachodniej, tekstu)" ${ }^{17}$. Wyrażony przez Jaworskiego pogląd zwraca uwagę na wymagania, jakie wobec czytelnika-badacza stawia poezja Tkaczyszyna-Dyckiego. Jednostronna interpretacja, która nie uwzględni obecnego tu napięcia między tekstem i egzystencją, może ześliznąć się w stronę odczytania naiwnego i powierzchownego. Równie niewystarczające wydaje się być orzekanie o przyjęciu przez poetę strategii gry albo o zachodzącej tam "dialektyce sensów". Być może wyznaczone przez Jaworskiego miejsce dyskursu Tkaczyszyna-Dyckiego - na pograniczu, marginesie, kresie, krawędzi - stanowi zachętę do poszukania języka opisu zainteresowanego znoszeniem podziału na podmiot i przedmiot, prawdę i fałsz, autentyzm i kreację.

\section{Existential-Phenomenological Reading of Eugeniusz Tkaczyszyn-Dycki's Poetry}

\section{Summary}

The article concentrates on the existential-phenomenological reading of Eugeniusz Tkaczyszyn-Dycki's poetry as it was proposed by Grzegorz Tomicki in his work Po obu stronach lustra. O poezji Eugeniusza Tkaczyszy$n a-D y c k i e g o$. It concentrates on showing the tension between creation and authenticity in Eugeniusz Tkaczyszyn-Dycki's poetry and on the resulting difficulty in using traditional concepts of author and of lyrical ' $I$ '.

Keywords: poetry, creation, authenticity, Eugeniusz Takczyszyn-Dycki

16 M. Jaworski, Rzeczywiste. Konkretne, w: Pokarmy. Szkice o twórczości Eugeniusza Tkaczyszyna-Dyckiego, red. P. Śliwiński, Poznań 2012, s. 220.

17 Tamże. 